\title{
A Novel Poly-herbal Formulation Hastens Diabetic Wound Healing with Potent Antioxidant Potential: A Comprehensive Pharmacological Investigation
}

\author{
Pulak Majumder ${ }^{1, *}$, Mathad Paridhavi ${ }^{2}$
}

\section{Pulak Majumder, ${ }^{1, *}$ Mathad Paridhavi}

'Research scholar, PRIST University, Thanjavour, Tamil Nadu, INDIA. ${ }^{2}$ Professor and Principal, Rajiv Gandhi Institute of Pharmacy, Trikaripur, Kerala, INDIA.

\section{Correspondence}

Dr. Pulak Majumder

Research scholar, PRIST University, Thanjavour, Tamil Nadu, INDIA.

Phone no : +91 7829807212

E-mail: pulak2007@gmail.com

History

- Submission Date: 30-05-2018;

- Review completed: 27-09-2018;

- Accepted Date: 20-11-2018

DOI : 10.5530/pj.2019.11.48

Article Available online

http://www.phcogj.com/v11/i2

\section{Copyright}

(c) 2019 Phcog.Net. This is an openaccess article distributed under the terms of the Creative Commons Attribution 4.0 International license.

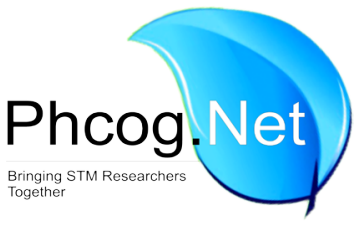

\begin{abstract}
Objective: Current investigation was aimed to evaluate the wound healing and antioxidant potentials of the novel Poly-herbal Formulation (PHF) in diabetic rat's models and in-vitro antioxidant assays respectively. Methods: The wound models viz., excision, incision and dead space by using wistar strain albino rats were adopted for this investigation. The free radical scavenging assays were employed for investigation of Antioxidant potential in poly herbal formulation. The constraints studied for assessment of wound repair were percentage closing percentage of wound, tensile strength of repaired tissue, breaking strength of granulation tissue and valuation of hydroxyproline content on dried tissue. The histopathological sections of granulation tissues obtained in dead space wound model were studied for the distribution of collagen and other histopathological changes. Four groups were used in this study with six animals each. Group I and Group II acts as normal control and diabetic control whereas Group III and Group IV was used as glibenclamide treated $(1 \mathrm{mg} / \mathrm{kg}$ b.w.) and PHF $(500 \mathrm{mg} / \mathrm{kg}$ b.w.) treated group respectively. On the other hand the various antioxidant assays like DPPH, scavenging assays, hydrogen peroxide assay etc. were investigated. Results: The PHF has been significantly healing the wounds in diabetic rats within 18 days, while diabetic control rats healed the wound about $86.12 \%$ in the same conditions and time. The wound breaking strength and histopathological studies of healed skin was signified the results. Significant $(p<0.01)$ increase in wound breaking strength as well as epithelialization and the level of hydroxyproline was observed in PHF treated animals comparison with diabetic control group. PHF has also shown significant antioxidant potential in in-vitro assays. Conclusion: All these investigation indicates the significant wound healing and antioxidant potential of PHF in the experimental animal groups in diabetic condition.
\end{abstract}

Key words: Poly herbal formulation, Diabetes, Wound model, Streptozotocin, Antioxidant.

\section{INTRODUCTION}

Wound is demarcated as the breakdown of community tissues by violence or trauma. The restoration of wounded or inflamed tissues back to normal condition is regarded as healing. The biological process involving tissue repair and regeneration conferred as wound healing. The process of healing is a complex progression of body tissue or skin. It is divided by three phase's i.e, hemostasis or blood clotting, inflammation, proliferation or new tissue development and maturation of tissue. ${ }^{1-2}$ Management of various metabolic ailments by poly-herbalism has been recognized in ancient documents like 'Sarangdhar Samhita' dated in 1300 A.D. The presence of various phyto-constituents leads to significant therapeutic efficacy when formulated together with compatible herbs in formulations. In traditional systems of medicine numerous classical poly-herbal formulations were described which illustrate better therapeutic effectiveness rather than recent medication. Instead of single phytochemicals it is evident that the multi-constituent formulations have better therapeutic consequence. Multiple therapeutic targets can be achieve at the same time with combination of phytochemicals. ${ }^{3}$ Though diabetic wound healing is a complex aliments, so the greater healing can be achieve with poly herbal formulation rather than mono herbs which also provides extended safety and enhances tolerability.

The underlying cause of Cellular injury is probably due to oxidative stress associated with diabetes complications like damage of tissue or dysfunction of organs. The oxidative stress increases reactive oxygen species that causes damage to bio-molecules like lipids, proteins and even DNA as well. The presence of various antioxidant enzymes such as super oxide dismutase, catalase, glutathione reductase etc. can reduce cellular oxidative stress in significantly. Therefore the antioxidant rich medicine can reduce the long term complications of diabetes wounds.

Cassia auriculata, ${ }^{4-5}$ Mangifera indica, ${ }^{6-7}$ Ficus banghalensis, ${ }^{8-9}$ Cinnamomum tamala ${ }^{10-11}$ and

Cite this article: A Novel Poly-herbal Formulation Hastens Diabetic Wound Healing with Potent Antioxidant Potential: A Comprehensive Pharmacological Investigation. Pharmacog J. 2019;11(2):324-31. 
Trichosynthis diocia, ${ }^{12-13}$ are well-known herbs available throughout India. All those referred herbs are reportedly used for wound and diabetes mellitus as well. The synergistic or combined effect of those herbs is still not explored in terms of healing of diabetes associated wounds despite its individualized reports. The objective of this current study is to access overall antioxidant and healing potentials in diabetic conditions by using standard clinical in vitro and in vivo methods.

\section{MATERIALS AND METHODS}

\section{Chemicals}

Streptozotocin (STZ) (Hi media, India), reagent of analytical grade (SD Fine chemical Ltd.), Standard Gallic acid (GA), Ellagic acid, Catechin and Epicatechin were received from Natural Remedies Ltd, Bangalore, India, as gift samples.

\section{Collection and authentication of the herbs}

Botanicals were obtained from Kerala, India and authenticated. Herbarium (voucher specimen) were prepared and deposited in the Department of Pharmacognosy. The voucher numbers were given for each herb as shown in Table 1.

\section{Preparation of aqueous extract}

All the procured phyto materials (Table 1) were shade dried, powdered separately and passed through \#20 sieves. Powder materials were macerated with distilled water $(1: 10)$ and aqueous extracts were put into lyophilisation process. Herbal formulation was prepared by these lyophilized plant extracts.

\section{Experimental Animals}

The stains of Wistar albino rats (weight $180 \pm 10 \mathrm{~g}$ ) of both sexes were used for the study. Polyacrylic cages were used in housed animals kept at standard condition with $24 \mathrm{~h}$ dark/light cycle and provided with free access to water and pellets diet. The anti-diabetic study protocol was executed as per to the guide lines of CPCSEA, Ministry of Environment and Forests, Govt. of India.

\section{Phytochemical investigation}

$1 \mathrm{gm}$ of individual aqueous extracts was dissolved in $100 \mathrm{ml}$ water to obtain a stock of concentration of $1 \% \mathrm{w} / \mathrm{v}$ and tested for the presence of carbohydrates, proteins, sterols, alkaloids, tannins, glycosides, flavonoids, phenolic compounds and saponins as per standard procedure. ${ }^{14}$

\section{Development of polyherbal formulation}

The dried lyophilized plant aqueous extracts were mixed in equal proportions with few $\mathrm{ml}$ of tween 80 solution and make the volume with water.

\section{In vitro antioxidant activity}

\section{Nitric oxide scavenging activity}

The reaction mixture $(5.0 \mathrm{ml})$ containing Sodium Nitro Prusside $(25 \mathrm{mM})$ in phosphate buffered saline ( $\mathrm{pH} 7.3$ ), with or without the plant extract at different concentrations and Incubated at $25^{\circ} \mathrm{C}$ for $180 \mathrm{~min}$ in front of a visible polychromatic light source ( $25 \mathrm{~W}$ tungsten lamp). The NO radical thus generated interacted with oxygen to produce the nitrite ion (NO) which was assayed at $30 \mathrm{~min}$ intervals by mixing $1.0 \mathrm{ml}$ of incubation mixture with an equal amount of Griess reagent (1\% sulfanilamide in 5\% phosphoric acid and $0.1 \%$ naphthylethylenediamine dihydrochloride). The absorbance of the chromophore (purple azo dye) formed during the diazotisation of nitrite ions with sulphanilamide and subsequent coupling with naphthylethylenediamine dihydrochloride was measured at $546 \mathrm{~nm}$. The nitrate generation was estimated from standard curve of known concentration of sodium nitrite. Each experiment was carried out at least three times and the data presented as an average of three independent determinations. The activity of poly herbal formulation was compared with ascorbic acid which was used as a standard antioxidant. The nitric oxide scavenging activity was calculated according to the following equation. ${ }^{15}$

$\%$ Inhibition $=[($ Absorbance of control - Absorbance of sample $) /$

(Absorbance of control) $] \times 100$

\section{Superoxide scavenging assay}

The superoxide radical generated from the photo reduction of riboflavin was detected by Nitroblue tetrazolium (NBT) reduction. The reaction mixture contained EDTA $(0.1 \mathrm{M})$ with $0.0015 \% \mathrm{NaCN}$, riboflavin (0.12 mM), NBT (1.5 mM) and various concentrations of extract $(10-100 \mu \mathrm{g} / \mathrm{ml})$ and phosphate buffer $(67 \mathrm{mM}, \mathrm{pH} 7.8)$ in a total volume of $3 \mathrm{ml}$. The tubes were uniformly illuminated for $15 \mathrm{~min}$ and optical density was measured at $530 \mathrm{~nm}$ before and after the illumination. The percentage inhibition was calculated by using Equation. ${ }^{16}$

$\%$ Inhibition $=[($ Absorbance of control - Absorbance of sample $) /$ (Absorbance of control) $] \times 100$

\section{DPPH (2, 2-diphenyl-1- picrylhydrazyl) assay}

Different concentrations of polyherbal extract were prepared in methanol ranging from $10 \mu \mathrm{g} / \mathrm{mL}$ to $100 \mu \mathrm{g} / \mathrm{mL}$. Standard DPPH solution $(0.1 \mathrm{mg} / \mathrm{ml})$ was prepared with methanol and mixed with test dilutions at a ratio of 1:3 in properly closed containers. The mixtures were kept in the dark at a room temperature for $90 \mathrm{~min}$. Absorbance of resulting solution was measured using spectrophotometer at $517 \mathrm{~nm}$. Scavenging activity was calculated by using equation. ${ }^{17}$

$\%$ Inhibition $=[($ Absorbance of control - Absorbance of sample $) /$ (Absorbance of control) $] \times 100$

The antioxidant activity is expressed as $\mathrm{IC}_{50}$. Ascorbic acid has used as standard. All the test was perform in triplicate.

Table 1: Authentication of herbs present in the Poly-herbal formulation.

\begin{tabular}{ccccc}
\hline Herbs & Family & Code & Part used & Voucher No \\
\hline Cassia auriculata L. & Caesalpiniaceae & CA & Flower & PG/CA/F-001 \\
Cinnamomum tamala & Lauraceae & CT & Leaves & PG/CT/L-003 \\
Ficus benghalensis L. & Moraceae & RB & Root bark & PG/FB/B-003 \\
Mangifera indica L. & Anacardiaceae & MI & Leaves & PG/MI/L-002 \\
Trichosanthes dioica & Cucurbitaceae & TD & Arial parts & PG/TD/AP-001 \\
\hline
\end{tabular}


Scavenging activity of ABTS (Azino-bis (3ethylbanzthiazoline-6- sulphonic acid) radicals

To prepare a dark colored ABTS working solution, ABTS solution $(7 \mathrm{mM})$ was mixed with potassium oxidopersulphate $(2.45 \mathrm{mM})$ solution and was placed in the dark for $12-16 \mathrm{~h}$. The solution was diluted with $50 \%$ methanol and absorbance was adjusted at $0.7( \pm 0.02)$ at $734 \mathrm{~nm}$. Extract $(100 \mu \mathrm{l})$ was mixed with $1 \mathrm{ml}$ of ABTS working solution and decrease in absorbance was read $1 \mathrm{~min}$ after adding the extract and then up to $6 \mathrm{~min}$. Percentage inhibition was calculated according to following formula. ${ }^{18}$

$\%$ Inhibition $=[($ Absorbance of control - Absorbance of sample $) /$

(Absorbance of control) $] \times 100$

$\mathrm{IC}_{50}$ values obtained as to determine the $50 \%$ inhibition of ABTS radicals.

\section{Hydrogen Peroxide scavenging activity}

PHF $(4 \mathrm{ml})$ prepared in distilled water at various concentration $(10-100 \mu \mathrm{g} / \mathrm{ml})$ was mixed with $0.6 \mathrm{ml}$ of $4 \mathrm{mM} \mathrm{H}_{2} \mathrm{O}_{2}$ solution prepared in phosphate buffer (0.1 M pH 7.4) and incubated for $10 \mathrm{~min}$. The absorbance of the solution was taken at $230 \mathrm{~nm}$. Ascorbic acid served as a positive control. The percentage of inhibition was calculated by comparing the absorbance values of the control and test samples using following equation. Percentage inhibition was calculated according to following formula:

$\%$ Inhibition= $($ Absorbance of control - Absorbance of sample $) /$ Absorbance of control $\times 100$

$\mathrm{IC}_{50}$ values obtained as to determine the $50 \%$ inhibition of $\mathrm{H}_{2} \mathrm{O}_{2}$ radicals.

\section{Acute oral toxicity study}

Six rats each in four groups were randomly selected and fasted overnight. Rats were administered PHF with increasing doses (250, 500, 1000, 2000 and $4000 \mathrm{mg} / \mathrm{kg}$ b.w.). The observational behavioral study done after one hour to detect any physiological changes like drowsiness, restlessness, writhing, convulsions, toxicity and mortality of animals. Same became repeated for the next $24 \mathrm{~h}$ and then at every $24 \mathrm{~h}$ for any signs of acute toxicity over the duration of 14 days. OECD guideline- 425 was referred for this acute toxicity study.

\section{Streptozotocin (STZ)-induced diabetic rat's model}

Freshly prepared STZ in citrate buffer induced to the experimental rats (50mg $/ \mathrm{kg} \mathrm{b.w)} \mathrm{by} \mathrm{ip} \mathrm{injection} \mathrm{of} 0.5 \mathrm{ml} / \mathrm{kg}$ b.w. ${ }^{19}$ Post induction of STZ, the rats were provided with glucose solution ( $5 \% \mathrm{w} / \mathrm{v}, 2 \mathrm{ml} / \mathrm{kg}$ b.w.) to preclude hypoglycaemic mortality. $300 \mathrm{mg} / \mathrm{dl}$ or more fasting glucose level was deliberated as diabetics. Wister albino Rats were separated randomly into four experimental groups, six rats each.

\section{Excision wound model}

The rats were inflicted with excision wounds as described by Morton and Malone (1972). ${ }^{20}$ Under light ether anesthesia a circular wound of about 500sq.mm. was made on depilated ethane sterilized dorsal thoracic region of rats. The wounds were divided into six groups of six each. The animals of group I and II were left untreated (Normal control and diabetic control.) Group III animals were served as reference standard, treated with glibenclamide $(1 \mathrm{mg} / \mathrm{kg}$ bw), animals of group IV were treated with PHF $(500 \mathrm{mg} / \mathrm{kg} \mathrm{bw})$, once a day/ po, starting from the day of operation, till complete epithelialization. The animals were housed individually. The wounds measurements were taken on $\mathrm{mm}^{2}$ graph paper on the post wounding days i.e., $6^{\text {th }}, 12^{\text {th }}, 18^{\text {th }}$ days. The percentage of wound closure (\% contraction) and period of epithelialization (number of days required for falling of the dead tissue remnants of the wound without any residual raw wound) were calculated.

\section{Determination of Percentage Wound Contraction ${ }^{19}$}

$$
\% \text { wound contraction }=\frac{\left(\text { Wound area of } 1^{\text {st }} \text { day }-\right.}{\text { Wound area on } \left.\mathrm{N}^{\text {th }} \text { day }\right)} \times 100
$$

\section{Incision wound model}

The method of Enrlich and Hunt ${ }^{21}$ was adapted for incision wound model. Under light ether anesthesia, $6 \mathrm{~cm}$ long Para vertebral incisions were made through the full thickness of the skin on either side of the vertebral column. The wounds were closed with interrupted sutures of $1 \mathrm{~cm}$ apart. The animals were divided into six groups of six animals each. The animals were left undressed and housed separately. The animals of group I and II left untreated, the group III served as reference standard and received Glibenclamide $(1 \mathrm{mg} / \mathrm{kg} \mathrm{bw})$. The animals of group IV were treated with PHF $(500 \mathrm{mg} / \mathrm{kg}$, bw) once a day from the day of operation till complete healing. The sutures were removed on $8^{\text {th }}$ post wounding day and the skin breaking strength of the wounds were measured on the $10^{\text {th }}$ day according to the continuous constant water flow technique of Lee et al. $^{22}$ as follows:

The anaesthetized rat was placed on operation table. The Allis forceps were firmly applied on the lines, facing each other. The forcep on one side was hooked to a metal rod, fixed firmly to the operation table, while the other to a light polythene container through a string runs over a pulley. Water was allowed to flow at a constant rate into the polythene container so as to build a gradual pulling force necessary to disrupt the wound. The flow of water was regulated by means of an occlusion clamp on rubber tubing connected to a reservoir, kept at a suitable height. The experiment stops with the gapping of wound observed with constant flow of water. The volume of water in the polythene container was measured and converted to the corresponding weight assuming the density to be equal to 'one'. The tensile strength was expressed as the minimum weight of water necessary to bring about the gaping of the wound.

\section{Dead space wound model}

Sterilize cylindrical grass piths $(2.5 \mathrm{~cm} \times 0.3 \mathrm{~cm})$ were implanted subcutaneously in the groin region of experimental animals under light ether anesthesia. ${ }^{23}$ The animals were divided into four groups of six each. The group I and II animals were left untreated and served as normal control and diabetic control. Group III and group IV animals received oral suspensions of Glibenclamide ( $1 \mathrm{mg} / \mathrm{kg} \mathrm{bw}$ ) and PHF ( $500 \mathrm{mg} / \mathrm{kg} \mathrm{bw}$ ) respectively. The granulation tissues formed around the piths were carefully harvested on the $10^{\text {th }}$ post wounding day. The wet weight and the breaking strength of the granulation tissue was measured by the method of Lee et al. ${ }^{23}$ as described already under incision wound model. The excised granulation tissue was dried at $60^{\circ} \mathrm{C}$ for $24 \mathrm{~h}$ and weighed. $5 \mathrm{ml}$ of $6 \mathrm{~N}$ Hydrochloric acid was further added with the dry tissue, kept heated for $24 \mathrm{~h}$ at $110^{\circ} \mathrm{C}$ and used for estimation of hydroxyproline. ${ }^{24}$

\section{Histopathological studies}

Wet granulation tissues were subjected to histopathological examinations. Tissues were fixed formalin solution (10\%) for $24 \mathrm{~h}$ and dehydrated with ethanol-xylene series of solutions. ${ }^{25,26}$ The tissue was then impregnated in molten paraffin and xylene $(1: 3)$ and incubated at $60^{\circ} \mathrm{C}$ for $1 \mathrm{~h}$. Then transferred to a vessel containing molten paraffin and xylene (1:1) and then to another vessel containing molten paraffin and xylene (3:1) and incubated at $60^{\circ} \mathrm{C}$. Microtone sections were taken at 5-10 $\mu$ thickness. 
The sections were then hydrated by passing through decreasing grades of alcohol and finally distilled water. The hydrated tissue sections were stained with haematoxylin for a few min and washed with ammonia water and then with distilled water. The sections were carefully dehydrated with ascending grades of alcohol-xylene mixtures (1:3, 1:1 and $3: 1$ ) and counter stained with eosin and then dehydrated with alcohol. The sections were observed for histopathological changes under a microscope and photographs of the same were taken for interpretation of results.

\section{Collagen estimation (Hydroxyproline content) ${ }^{24}$}

For the preparation of protein hydrolysate, $50 \mathrm{mg}$ of tissue sample in $1.0 \mathrm{ml}$ of $6.0 \mathrm{~N} \mathrm{HCl}$ was weighed and sealed in screw-capped glass tube. The tubes were autoclaved at 151.056 kilograms per $\mathrm{cm}^{2}$ for $3 \mathrm{~h}$. The hydrolysate was neutralized to $\mathrm{pH} 7.0$ and brought to the appropriate volume. Test tubes marked as sample, standard and blank were taken. One $\mathrm{ml}$ of test sample was added to test tubes marked as sample, $1.0 \mathrm{ml}$ of de-mineralized water to test tubes marked as blank and $1.0 \mathrm{ml}$ standard solutions to test tubes marked as standard. One $\mathrm{ml}$ of $0.01 \mathrm{M}$ Copper sulphate solution was added to all the test tubes followed by the addition of $1.0 \mathrm{ml}$ of $2.5 \mathrm{~N}$ Sodium hydroxide and $1.0 \mathrm{ml}$ of $6 \%$ Hydrogen peroxide. The solutions were occasionally mixed for $5 \mathrm{~min}$ and then kept for $5 \mathrm{~min}$ in a water bath at $80^{\circ} \mathrm{C}$. Tubes were chilled in ice-cold water bath and $4.0 \mathrm{ml}$ of $3.0 \mathrm{~N}$ Sulphuric acid was added with agitation. Two $\mathrm{ml}$ of $p$-(dimethylamino) benzaldehyde was then added and heated in water bath at temperature $70^{\circ} \mathrm{C}$ for $15 \mathrm{~min}$. The absorbance was measured at $540 \mathrm{~nm}$ using UV spectrophotometer. The hydroxyproline content of the samples were determined by interpolating the O.D. values on the standard graph.

\section{Statistical analysis}

The data obtained from each experiment were subjected to one-way ANOVA followed by Turkey's Multiple Comparison test. The F values, $\mathrm{dF}$ values and $P$ values were analyzed and recorded in respective tables.

\section{RESULTS}

\section{Phytochemical screening}

Preliminary phytochemical screening of PHF publicized the presence of phytochemicals like alkaloids, glycosides, saponins, tannins, flavonoids and phenolic compounds.

\section{In vitro antioxidant activity \\ Nitric oxide scavenging activity}

PHF showed a significant $(p<0.05)$ free radical scavenging action in concentration dependent manner against nitric oxide (NO) induced release of free radicals compared to standard ascorbic acid. The $\mathrm{IC}_{50}$ values of standard drug and PHF were found to be $21.30 \mathrm{mM}$ and $36.62 \mathrm{mM}$ (Figure 1).

\section{Superoxide radical scavenging activity}

The PHF showed superoxide radical scavenging activity in a concentration dependent manner. HAE and ascorbic acid exhibited $44.32 \%$ and $32.21 \%$. Results showed by the PHF was statistically significant $(p<0.05)$ compared to standard drugs (Figure 2).

\section{DPPH Assay}

The percentage inhibition of PHF and the standard ascorbic acid were found to be $34.65 \%$ and $31.20 \%$, respectively. The PHF exhibited concentration-dependent radical scavenging activity, which clearly indicates the dose-dependent DPPH scavenging action (Figure 3).

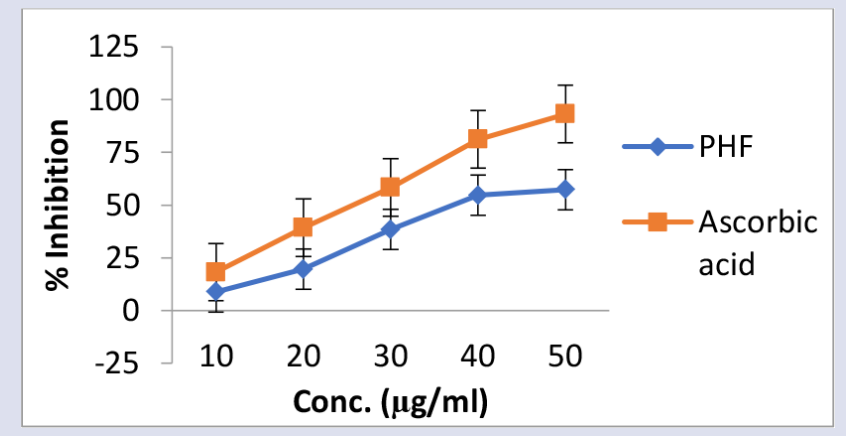

Figure 1: Nitric oxide scavenging activity.

Values are expressed as mean \pm standard deviation $(n=3) . \%$ scavenging activity of PHF is statistically significant at $p<0.05$, compared ascorbic acid (standard).

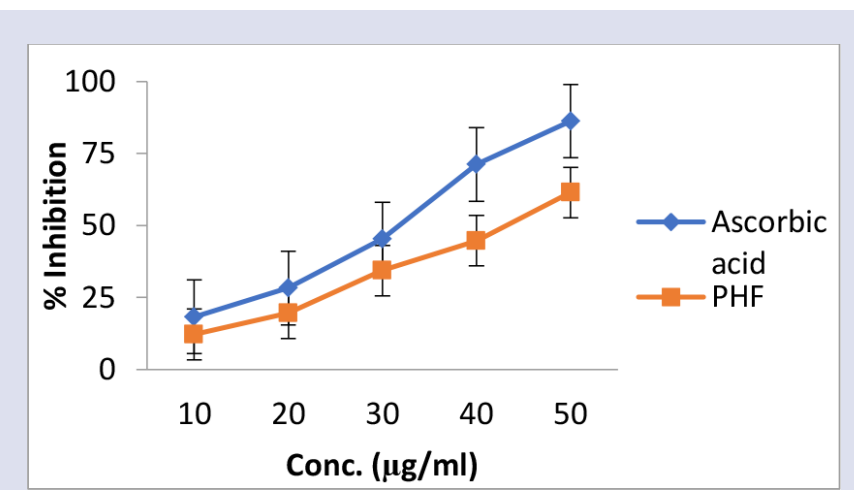

Figure 2: Superoxide radical scavenging activity. Values are expressed as mean \pm standard deviation $(n=3) . \%$ scavenging activity of PHF is statistically significant at $p<0.05$, compared ascorbic acid (standard).

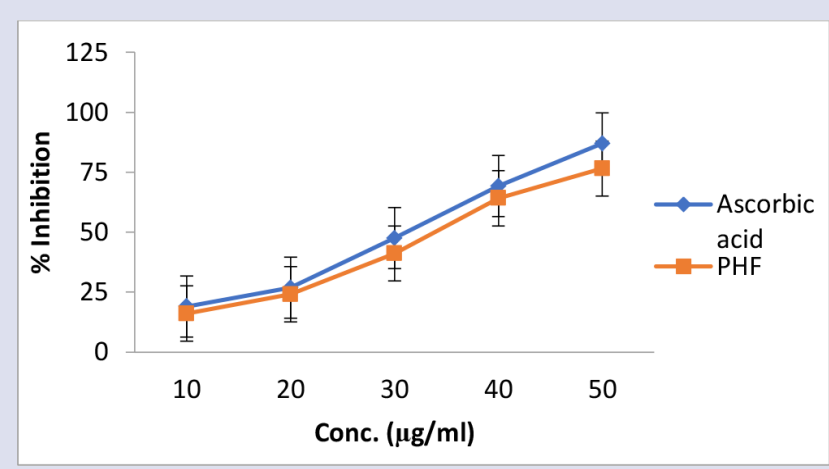

Figure 3: DPPH scavenging activity. Values are expressed as mean \pm standard deviation $(n=3) . \%$ scavenging activity of PHF is statistically significant at $p<0.05$, compared ascorbic acid (standard). DPPH = 1, 1-diphenyl-2-picryl hydrazyl. 


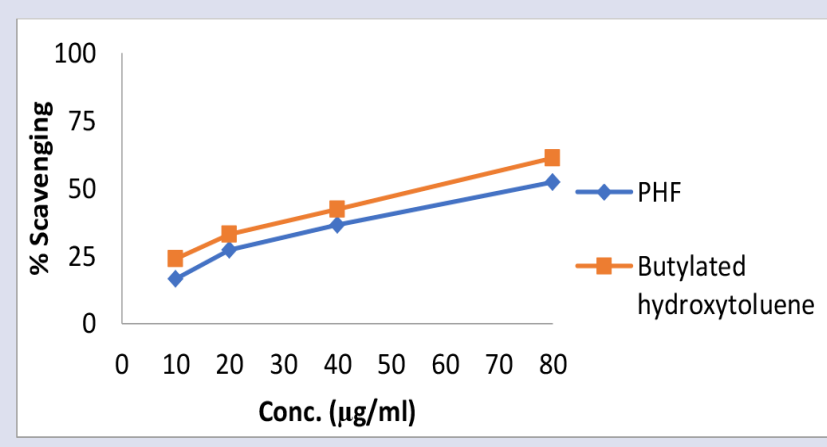

Figure 4: Scavenging activity of ABTS radicals.

Values are expressed as mean \pm standard deviation $(n=3) . \%$ scavenging activity of PHF is statistically significant at $p<0.05$, compared to Butylated hydroxytoluene. ABTS (Azino-bis (3- ethylbanzthiazoline-6- sulphonic acid).

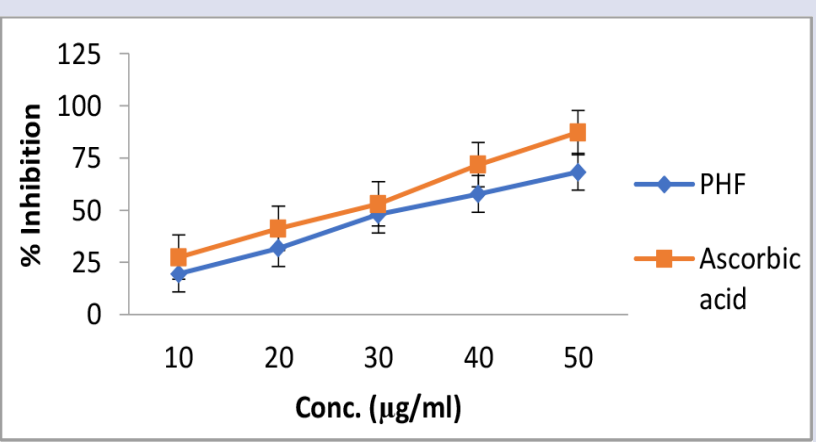

Figure 5: Hydrogen Peroxide scavenging activity. Values are expressed as mean \pm standard deviation $(n=3) . \%$ scavenging activity of PHF is statistically significant at $p<0.05$, compared to ascorbic acid.

\section{Scavenging activity of ABTS radicals}

Proton radical scavenging is an important attribute of antioxidants. ABTS is a protonated radical that has a characteristic maximum at $734 \mathrm{~nm}$, which decreases with the scavenging of proton radicals. PHF shows the ABTS scavenging ability (Figure 4). The scavenging effect of ABTS radical increased with concentration. The PHF showed antioxidant activities, proving their capacity to scavenge ABTS.

\section{Hydrogen Peroxide scavenging activity/ Hydroxyl radical scavenging}

The potential of PHF inhibit hydroxyl-radical-mediated deoxyribose damage. The PHF and ascorbic acid exhibited scavenging activity of $34.12 \%$ and $27.92 \%$ respectively. It was showing that the hydroxyl radical scavenging activity occurred in a dose-dependent manner (Figure 5).

\section{Acute oral toxicity study}

Acute toxicity study revealed the non-toxic nature of PHF; there was no mortality, breathing, cutaneous effects, sensory nervous system responses and gastrointestinal effects or signs of behavioral changes or toxicity observed after oral administration of up to the dose of $2000 \mathrm{mg} / \mathrm{kg}$. This study showed the single dose of PHF even at higher dosage does not produce any toxic symptoms indicating high margin of safety of extracts.

\section{Evaluation of wound healing activity}

The wound healing activities of PHF was evaluated employing three different animal models viz., excision, incision and dead space wound models. In all the models studied, significant wound healing activity was observed.

In excision wound model the parameters studied were percentage wound closure and mean epithelialization time. Significant wound healing activity was observed in the animals treated with PHF (Figure 6) compared to standard Glibenclamide treated group (Figure 6). The percentage of wound closure and percentage wound contraction as observed on $18^{\text {th }}$ day in PHF treated group were $1.04 \pm 1.07$ Sq.mm and $99.86 \pm 0.11 \%$ respectively compare to diabetic control $25.52 \pm 2.1$ Sq.mm and $86.12 \pm 0.94 \%$ respectively. The mean epithelialization time was also comparatively less in PHF treated groups when compared to diabetic control (Table 2 and Figure 7).

In the incision wound model the parameter studied was wound breaking or tensile strength of wounds. The results are furnished in Table 3. The results of the various parameters studied under dead space wound model (Figure 8) such as tensile strength/breaking strength of granulation tissue, wet and dry weight of granulation tissue and hydroxyproline content of the granulation tissue are shown in Table 4 . The animals treated with PHF exhibited significant tensile strength $(389.68 \pm 0.52 \mathrm{~g})$ on the post wounding day 10 compared to the reference standard treated group (350.54 $\pm 0.31 \mathrm{~g})$.

The tensile strength of the granulation tissue in PHF treated animals was significant $(389.68 \pm 0.52 \mathrm{~g})$ when compared to that of diabetic control group $(268.55 \pm 0.12 \mathrm{~g})$. The weight of the dry granulation tissue was also more significant in the animals treated with PHF $(32.33 \pm 0.55 / 100 \mathrm{~g}$ rat) when compared to diabetic control $(18.68 \pm 0.4 \mathrm{mg} / 100 \mathrm{~g}$ rat). The hydroxyproline content of the granulation tissue followed the same pattern as that of tensile strength. Hydroxyproline content of granulation

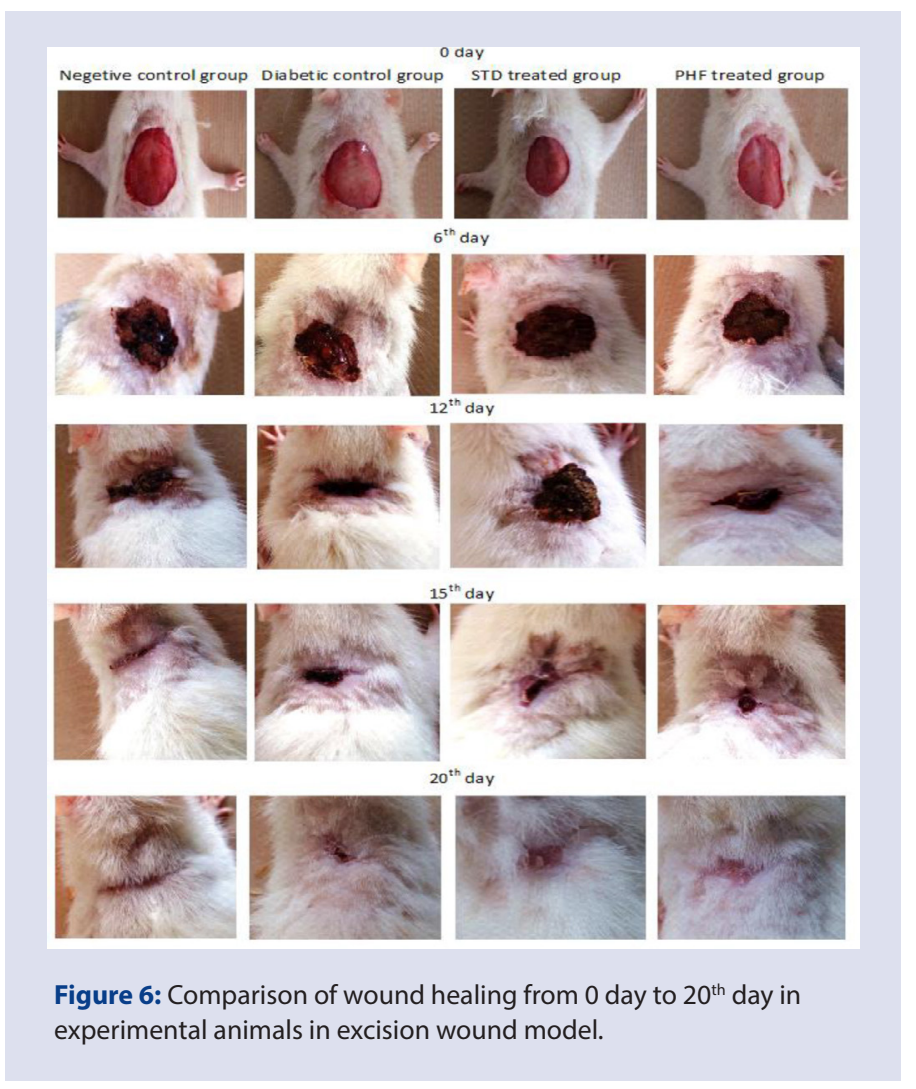


Table 2: Effect PHF on excision wound model.

\begin{tabular}{|c|c|c|c|c|c|}
\hline & Day 1 & Day 6 & Day 12 & Day 18 & Day 21 \\
\hline Negative control & $491.39 \pm 1.35$ & $246.35 \pm 2.10$ & $101.23 \pm 1.63$ & $1.63 \pm 1.23^{*}$ & --- \\
\hline (\%wound closure) & $0.00 \%$ & $50.06 \pm 2.77$ & $79.25 \pm 1.95^{*}$ & $99.69 \pm 0.31$ & --- \\
\hline Diabetic control & $532.49 \pm 1.26$ & $259.51 \pm 2.3$ & $117.08 \pm 1.24$ & $25.52 \pm 2.1$ & $11.51 \pm 0.21$ \\
\hline (\%wound closure) & $0.00 \%$ & $50.07 \pm 3.21$ & $77.44 \pm 3.16$ & $86.12 \pm 0.94$ & $89.82 \pm 0.36$ \\
\hline Glibenclamide treated & $531.45 \pm 2.35$ & $305.61 \pm 3.01$ & $96.61 \pm 2.36$ & $12.1 \pm 1.25$ & $4.84 \pm 1.02$ \\
\hline (\%wound closure) & $0.00 \%$ & $42.38 \pm 1.37$ & $81.65 \pm 2.37$ & $93.66 \pm 0.83$ & $97.04 \pm 0.55$ \\
\hline PHF treated & $465.73 \pm 2.62$ & $268.93 \pm 1.51$ & $76.76 \pm 1.02^{*}$ & $1.04 \pm 1.07^{*}$ & ---- \\
\hline (\%wound closure) & $0.00 \%$ & $41.71 \pm 2.35$ & $83.66 \pm 1.65$ & $99.86 \pm 0.11$ & --- \\
\hline
\end{tabular}

$\mathrm{n}=6$ in each group. Values are represented as mean \pm SEM. ${ }^{*} p<0.05$ as compared to diabetic control (Tukey’s Kramer multiple comparison test).

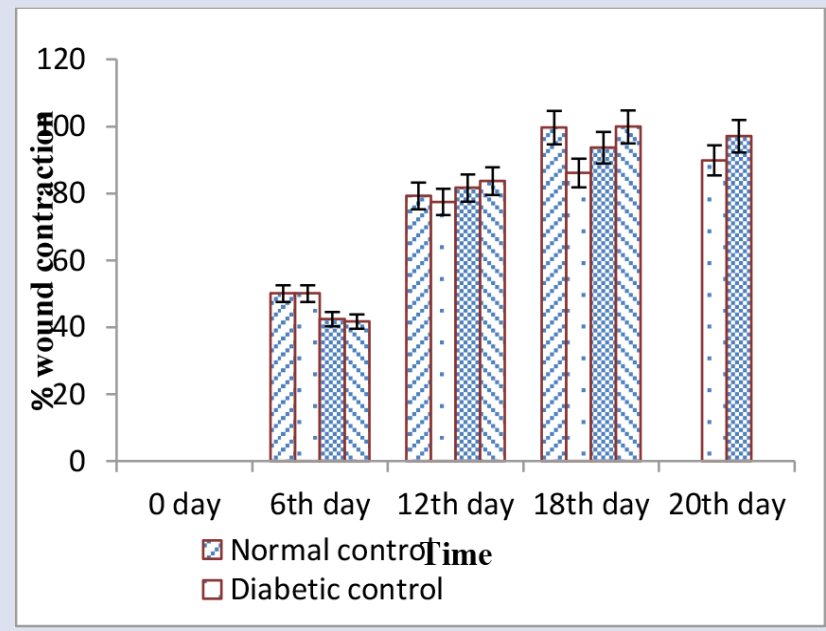

Figure 7: Percentage wound contraction in excision wound model.

Table 3: Breaking strength of granulation tissue in incision wound model.

\begin{tabular}{cc}
\hline Groups & Breaking strength $(\mathbf{g})$ \\
\hline Normal Control & $347.5 \pm 0.25$ \\
Diabetic control & $268.55 \pm 0.12$ \\
Glibenclamide & $350.54 \pm 0.31$ \\
PHF & $389.68 \pm 0.52^{*}$ \\
\hline
\end{tabular}

$n=6$ in each group. Values are represented as mean \pm SEM. ${ }^{*} p<0.05$ as compared to diabetic control (Tukey Kramer multiple comparison test).

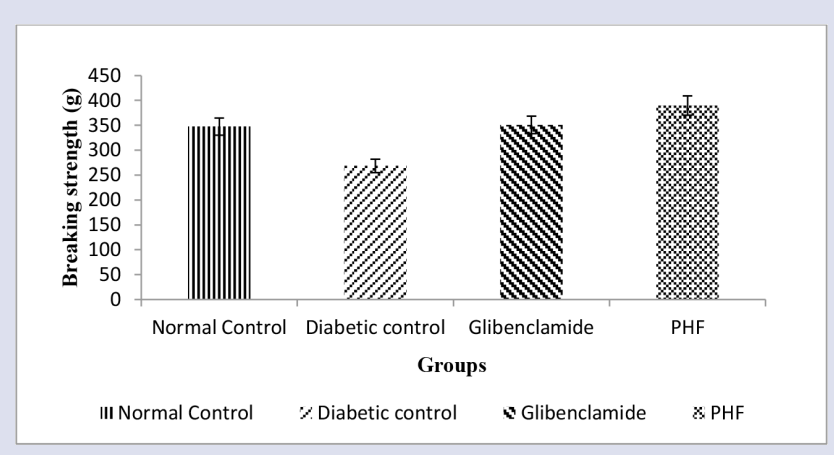

Figure 8: Breaking strength of granulation tissue.
Table 4: Effect PHF on dead space wound model.

\begin{tabular}{ccccc}
\hline & $\begin{array}{c}\text { Negative } \\
\text { control }\end{array}$ & $\begin{array}{c}\text { Diabetic } \\
\text { control }\end{array}$ & Glibenclamide & PHF \\
\hline $\begin{array}{c}\text { Granulation } \\
\text { tissue dry weight } \\
(\mathrm{mg} / 100 \mathrm{~g} \text { body } \\
\text { weight })\end{array}$ & $26.16 \pm 0.52$ & $18.68 \pm 0.4$ & $21.76 \pm 0.24^{*}$ & $32.33 \pm 0.55^{*}$ \\
$\begin{array}{c}\text { Granulation } \\
\text { tissue wet weight } \\
(\mathrm{mg} / 100 \mathrm{~g} \text { body } \\
\text { weight })\end{array}$ & $52.53 \pm 0.46$ & $46.05 \pm 0.49$ & $48.61 \pm 0.77$ & $58.03 \pm 0.64^{*}$ \\
$\begin{array}{c}\text { Hydroxyproline } \\
(\mu \mathrm{g} / 100 \text { mg }\end{array}$ & $29.33 \pm 0.49$ & $21.73 \pm 0.31$ & $24.19 \pm 0.17^{*}$ & $32.62 \pm 0.21^{*}$ \\
granulation tissue $)$ & & & & \\
\hline
\end{tabular}

$\mathrm{n}=6$ in each group. Values are represented as mean \pm SEM. ${ }^{*} p<0.05$ as compared to diabetic control (Tukey Kramer multiple comparison test).

tissue obtained from animals treated with PHF was comparatively more significant $(32.62 \pm 0.21 \mathrm{mg} / \mathrm{g}$ tissue) when compared to that of diabetic control (21.73 $\pm 0.31 \mathrm{mg} / \mathrm{g}$ tissue) (Table 4 and Figure 9).

The PHF was found to be more efficient as evidenced by the histopathological studies of the granulation tissues. The negative control group showed fibroadipose tissue with adnexal structures [Figure 10] and granulation tissue consisting of predominantly proliferating vascular spaces, inflammatory cells and plump fibroblasts. Whereas in diabetic control group showed inflammatory cells and abundant plump fibroblasts [Figure 10] as like negative control. Increase number of macrophages, insignificant collagenation and vascularization also evident in diabetic control animals. PHF showed adipose tissue with a lymphnode [Figure 10] consisting of mixed population of lymphoid cells [Figure 10] with significant collagenation, less macrophages and well-formed capillaries. Glibenclamide treated group showed [Figure 10] the granulation tissue consisting of proliferating and congested vascular spaces, inflammatory cells and abundant plump fibroblasts [Figure 10].

\section{DISCUSSION}

The concept of poly-pharmacy has been practicing since from ancient time. The proven examples are listed in various Ayurveda literatures. The poly-herbal formulation was formulated using the lyophilized aqueous extracts of the dried flower of Cassia auriculata L., dried leaves of Mangifera indica, dried root barks of Ficus banghalensis, dried leaves of Cinnamomum tamala and dried whole plant of Trichosynthis diocia, which are mixed properly. The aqueous extract has been used to minimize the residual solvent toxicity. 


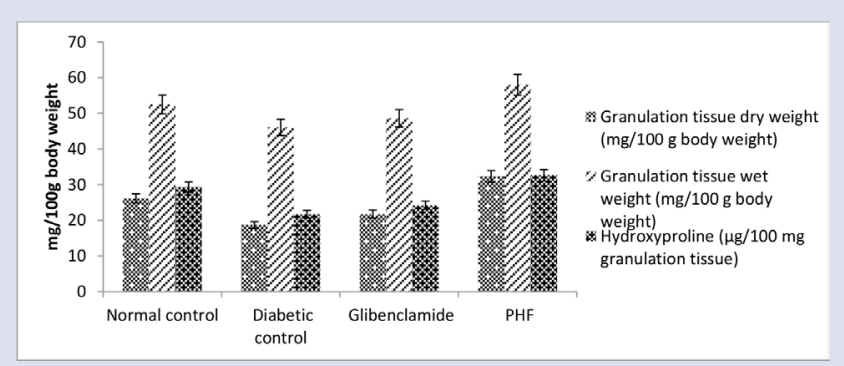

Figure 9: Dry weight, Wet Wight and Hydroxyproline content in granulation tissue.

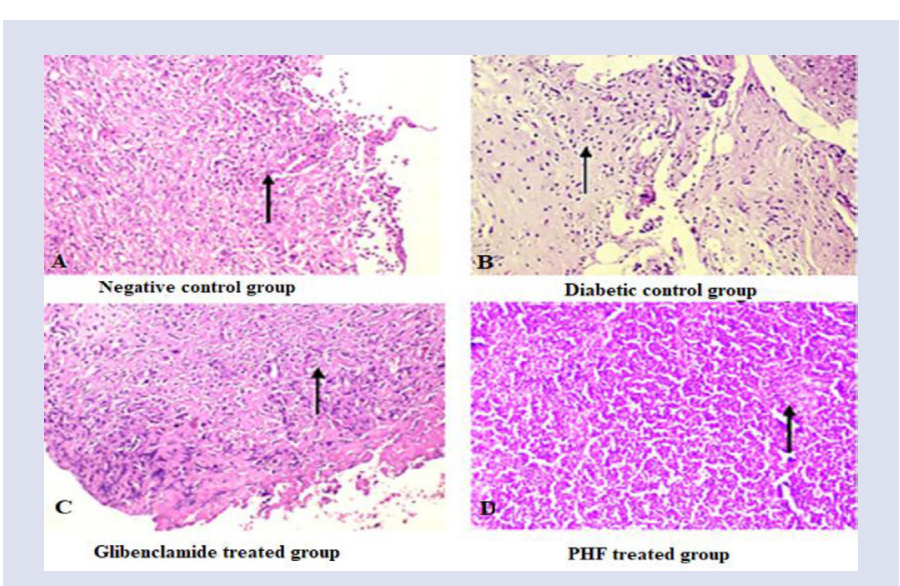

Figure 10: Histopathological study of granulation tissue in wound groups.

The wound healing and blood sugar lowering activity of some individual plants has been reported along with their antioxidant properties. The poly-herbal formulation (PHF) majorly composed of phytochemicals like, alkaloids, tannins, glycosides, flavonoids, phenolics and saponins etc. Flavonoids and polyphenols are natural antioxidants, reported to significantly increase SOD, glutathione and catalase activities. ${ }^{27}$ Hence the poly-herbal formulation showed a significant antioxidant property as compared with various standards like ascorbic acid or butylated hydroxytoluene. The endothelial dysfunctions due to hyperlipidemia, hyperinsulinemia and hyperglycemia are the result of oxidative stress. ${ }^{28}$ The reduction of antioxidant enzymes, inactivation of enzymes and lipid peroxidation cause cell death while free radicals get excess produces. The presence of significant amount of total phenolic and flavonoids make this formulation potent scavenging and antioxidants in biological systems. PHF showed scavenging activity were expressed in terms of $\%$ inhibition of generated free radicals respectively with respect to various concentrations. Concentration dependent effects were observed in each case. As per different studies, it was reported that there is an increase in free radicals formation in Diabetes mellitus and simultaneously decrease in antioxidant property. Different studies have shown that Diabetes mellitus is associated with the increased formation of free radicals and decrease in antioxidant potential which leads worsen the condition of wounds.

Wound management in diabetes is a complex and hindered process. Call proliferation and collagenation process get suppress due to hyperglycemia. ${ }^{16}$ In this present investigation, the different process of collagenation and granulation was hastened by PHF in diabetic rats. The suggested mechanism behind the hastening process of wound repair may due to the potent antioxidant properties, free radical scavenging, anti-inflammatory and astringent as well as immune modulatory property which may done due to the presence of various phytochemicals. Flavonoids like keampferol and quercetin, phenols and tannin are reported for its better collagenation and epithelialization activity which due to its scavenging activity. ${ }^{17}$ The other constituents like alkaloids or tannins of PHF also possess antimicrobial activity ${ }^{23}$ towards Staphtococcus aureus and Pseudomonas aeruginosa responsible for diabetic foot ulcer. Hence it is concluded that the PHF have significant wound healing activity in diabetes and it may also be suggested for treating other kind of wounds in human beings.

\section{CONCLUSION}

Fibroplasia, collagenation and contraction are the multiple pathophysiological mechanisms of wound healing commenced by various active principles. The clinical condition like diabetes which alters the process of wound healing. Developed PHF has been found effective to lower the blood glucose level significantly after administration. This PHF has rich with alkaloids, tannins and flavonoids glycosides are well known for its anti-inflammatory and antioxidant actions, which also potentiate faster healing of wounds. This formulation will provide a fruitful solution for diabetic wound management and care.

\section{ACKNOWLEDGEMENT}

Authors are thankful to the Principal and Managements of Acharya and BM Reddy College of pharmacy for providing adequate facilities and encouragements for accomplishment of this research work.

\section{CONFLICT OF INTEREST}

The authors declared no conflict of interest.

\section{ABBREVIATIONS}

PHF: Poly herbal formulation.

\section{REFERENCES}

1. Mustoe TA, Gurjala A. The role of the epidermis and the mechanism of action of occlusive dressings in scarring. Wound Repair and Regeneration. 2011;19(1):S16-21.

2. Guo S, DiPietro LA. Factors affecting wound healing. J Dental Res. 2010;89(3):219-9

3. Chorgade MS. Drug Discovery and Development. Hoboken, New Jersey: John Wiley and Sons Inc. 2007.

4. Surana SJ, Gokhale SB, Jadhav RB, Sawant RL, Jyoti B. Anti-hyperglycemic activity of various fractions of Cassia auriculata in alloxan diabetic rats. Indian $\mathrm{J}$ Phar Sci. 2008;70(2):227-9.

5. Pari L, Latha M. Effect of Cassia auriculata flowers on blood sugar levels, serum and tissue lipids in streptozotocin diabetic rats. Singapore Med J. 2002;43(12):617-1.

6. Luka CD, Mohammed A. Evaluation of the antidiabetic property of aqueous extract of Mangifera indica leaf on normal and alloxan-induced diabetic rats. $J$ Nat Prod Plant Resour. 2012;2(2):239-43.

7. Amrita B, Liakot A, Masfida A, Begum R. Studies on the anti-diabetic effects of Mangifera indica stem-barks and leaves on non-diabetic, type 1 and type 2 diabetic model rats. Bangladesh J Pharmacol. 2009;4:110-4.

8. Mahalingam G, Krishnan K. Antidiabetic and Ameliorative potential of Ficus bengalensis bark extract in streptozotocin induced diabetic rats. Ind J Clinical Biochem. 2008;23(4):394-400.

9. Venkanna BB, Prabhu KM, Murthy PS. Studies on the hypoglycaemic activity of the bark of Ficus bengalensis employing alloxan recovered rabbits. Diabetes Bulletin. 1987;7:105-7.

10. Chakraborty $U$, Das $\mathrm{H}$. Antidiabetic and antioxidant activities of Cinnamomum tamala leaf extracts in stz-treated diabetic rats. Global J. Biotec and Biochem. 2010;5(1):12-8.

11. Shradha B, Sisodia SS. Assessment of anti-diabetic potential of Cinnamomum tamala leaves extract in streptozotocin induced diabetic rats. Ind J Pharmacol. 
2011;43(5):582-5.

12. Rai PK, Jaiswal D, Rai DK, Sharma B, Watal G. Effect of water extract of Trichosanthes dioica fruits in Streptozotocin induced diabetic rats. Ind J Clinical Biochem. 2008;23(4):387-400.

13. Shalini A, Bairy KL, Meharban A, Punita ISR. Hypoglycemic effect of aqueous extract of Trichosanthes dioica in normal and diabetic rats. Int J Diab Ctries. 2010;30(1):38-2.

14. Petchi RR, Parasuraman S, Vijaya C. Antidiabetic and antihyperlipidemic effects of an ethanolic extract of the whole plant of Tridax procumbens (Linn.) in streptozotocin-induced diabetic rats. J Basic Clin Pharm. 2013;4(4):88.

15. Marcocci L, Maguire JJ, Droy-Lefaix MT, Packer L. The nitric oxide scavenging properties of Ginkgo biloba extract EGb761. Biochem and Biophys. Research communication. 1994;201(12):748-55.

16. McCord JM, Fridovich I. Superoxide dismutase: an enzymic function for erythrocuprein (hemocuprein). J Biol Chem. 1969;244(22):6049-5.

17. Brand WW, Cuvelier ME, Berset $C$. Use of a free radical method to evaluate antioxidant activity. Lebensmittel-Wissenschaft und-Tech. 1995;28(1):25-30.

18. Re R, Pellegrini N, Proteggente A, Pannala A, Yang M, Rice EC. Antioxidant activity applying an improved ABTS radical cation decolorisation assay. Free Rad Bio Med. 1999;26(9-10):1231-7.

19. Hema SD, Shankar KM, Bhushan P. Wound healing activity of topical application forms based on Ayurveda. Evidence Based Comp and Alt Med. Oxford University
Press. 2009.

20. Morton JJ, Malone MH. Evaluation of vulnerary activity by an open wound procedure in rats. Arch Int Pharmacodyn Ther. 1972;196(1):117-6.

21. Enrlich HP, Hunt TK. Effect of cortisone and vitamin A on wound healing. Ann Surg. 1968; 167:324-8.

22. Lee KH. Studies on the mechanism of action of Salicylates II- Retardation of wound by aspirin. J Pharm Sci. 1968;57(6):1042-3.

23. Kuppast IJ, Kusum S, Akki PV, Hukkeri VI. Wound healing activity of Polianthes tuberose bulb extracts. Ind J Nat Prod. 2006:22(2):10-3.

24. Neuman PE, Logan MA. The determination of collagen and elastin in tissues. $J$ Biochem.1972;186(2):549-56

25. Kanai LM. Medical laboratory Technology. New Delhi McGraw-Hill Ltd. New Delhi. 2000.

26. Harsh Mohan. Text book of Pathology, $5^{\text {th }}$ edition. Jaypee Brother Medical Publishers (P) Ltd, New Delhi. 2006;14-6.

27. Shivananda N, Poorna N, Steve S, Vidyasagar B, Andrew A. Evaluation of wound healing activity of Allamanda cathartica. L. and Laurus nobilis. L. extracts on rats. BMC Comp and Alt Med. 2006;6(1):12.

28. Minh CN, Dinh TL, Kaeko K, Thi PTD. Wound healing activity of Streptocaulon juventas root ethanolic extract. Wound repair and regeneration. 2017;25(6):956-3.

Cite this article: A Novel Poly-herbal Formulation Hastens Diabetic Wound Healing with Potent Antioxidant Potential: A Comprehensive Pharmacological Investigation . Pharmacog J. 2019;11(2):324-31. 